\title{
Effect of Education on Quality of Life and Well Being
}

\author{
Sarah Javed $^{1 *}$, Salma Javed ${ }^{2}$, Arfa Khan ${ }^{3}$
}

\section{ABSTRACT}

One does not need to look far to find plenty of evidences of the influence of education on many important aspects of people's lives. So, if 'happiness' is understood in the robust eudaemonist sense of key for perfect living, then education evidently has an enormous impact. Education has become one of the clearest indicators of life outcomes such as employment, income and social status, and is a strong predictor of attitudes, wellbeing, good Quality of Life etc. Following Objectives were formed for the study: (i) To Assess and Compare Quality of Life of educated and uneducated Muslim Housewives. (ii) To assess and compare Well-Being of educated and uneducated Muslim housewife. 100 educated Muslim Housewives and 100 uneducated Muslim housewives were taken from District Aligarh. Snow Ball sampling technique was used for gathering the data. WHOQOL-BREF was used to assess Quality of life and Well- Being Scale was used to assess various well-being dimensions in both the groups. Significant Difference was found between various dimensions of quality of life and well-being of educated and non educated Muslim women of Aligarh district.

Keywords: Education, Quality Of Life, Well-Being

"Education is a liberating force and in our age it is also a democratizing force, cutting across the barriers of caste and class, smoothing out inequalities imposed by birth and other circumstances." - Indira Gandhi

No country can achieve sustainable economic development without substantial investment in human capital. Education enriches people's understanding of themselves and world. It raises people's productivity and creativity and promotes entrepreneurship and technological advances. It's the education which transforms a person to live a better life and leads to broad social benefits to individuals and society. Education involves gathering of knowledge in whatever aspects. It

\footnotetext{
${ }^{1}$ Research Scholar, Department of Psychiatry, Jawaharlal Medical College, Aligarh Muslim University, India

${ }^{2}$ M.Phil in English, Department of English, Aligarh Muslim University, India

${ }^{3}$ Advanced Diploma in Counselling Psychology, Jamia Millia Islamia, India

*Responding Author

(C) 2016 I S Javed, S Javed, A Khan; licensee IJIP. This is an Open Access Research distributed under the terms of the Creative Commons Attribution License (http://creativecommons.org/licenses/by/2.0), which permits unrestricted use, distribution, and reproduction in any Medium, provided the original work is properly cited.
} 


\section{Effect of Education on Quality of Life and Well Being}

helps a person to draw the best or of their mind and spirit. Education plays a vital role in the personal growth and the social development among all of us.

\section{Education in Islam}

As our study is concerned with Muslim Females so I would like to throw some light on Education in Islam. Islam has, from its inception, placed a high premium on education and has enjoyed a long and rich intellectual tradition. Knowledge ('ilm) occupies a significant position within Islam, as evidenced by the more than 800 references to it in Islam's most revered book, the Koran. The importance of education is repeatedly emphasized in the Koran with frequent injunctions, such as "God will exalt those of you who believe and those who have knowledge to high degrees" (58:11), "O my Lord! Increase me in knowledge" (20:114), and "As God has taught him, so let him write" (2:282). Such verses provide a forceful stimulus for the Islamic community to strive for education and learning.

Equality of men and women is emphasized in Islam and they are complementary in nature to one another.

The Quran says : O men! Fear your Lord Who created you from a single being and out of it created its mate; and out of the two spread many men and women. (Sura An-Nisa, Sura \# 4, Aya \# 1)

This verse clearly expounds that men or women created from a single entity and are basically equal genders. As a gender one is not superior to the other and according to usage, women too have rights over men similar to the rights of men over women. That rights enjoyed by men are the duties of the women and the duties of men are the rights of women. This implies a similitude between both the genders. There is no light conferred on man that women may be deprived of because she is a woman. Islam entitles women to the same rights and men in terms of education. The Prophet of ALLAH (P. B. U. H.) said as reported and authenticated by the scholars; seeking knowledge is compulsory for each and every Muslim (i.e. both male and female).

\section{Well-Being and Quality of Life}

Conceptions and definitions of well-being and quality of life have changed across the decades. Initially the terms 'quality of life' and 'well-being' were conceptually different. Smith (1973) theorized well-being as a concept measuring the objective life conditions of the population in general, and quality of life as a subjective assessment of individuals' lives. Nearly four decades later, Gasper (2010) also argued that the two terms were conceptually different, but in the opposite way to Smith (1973), that is, he considered well-being applied more at individual level, and quality of life when discussing communities, localities, or societies. He acknowledged, though, the broad range of meanings that the terms have, and the frequent overlaps that occur (Gasper, 2010). 


\section{Effect of Education on Quality of Life and Well Being}

Still, most social studies use the term 'quality of life' in conjunction or interchangeably with 'well-being' (Veenhoven, 1999; Cummins, 2000; Easterlin, 2007; Michalos, 2007; Oswald, 2007 In words of Bradshaw, well-being has been defined as "Playing an active role in creating their well-being by balancing different factors, developing and making use of resources and responding to stress."

Shin and Johnson (1978) have defined well-being form of happiness as "a global assessment of a person's quality of life according to his own chosen criteria"

The WHO defines QOL as 'an individual's perception of their position in life in the context of the culture and value systems in which they live, and in relation to their goals, expectations, standards and concerns' .

Education has never mattered more than it does today. It is the new currency of the global economy. It is essential for success, and the more you have, the better off you - and your family will be. The question arises what impact education has on Quality of life and well-being of Muslim women. In order to get answer of it this study was conducted keeping in mind the following objectives.

\section{Objectives}

1. To Assess and Compare Quality of Life of educated and uneducated Muslim Housewives.

2. To assess and compare Well-Being of educated and uneducated Muslim housewife

\section{METHODOLOGY}

\section{Research Tools}

Following research tools were used in the study

1. The WHOQOL-BREF is an abbreviated 26-item version of the WHOQOL-100 containing items that were extracted from the WHOQOL-100 field trial data. It yield scores in four domains: Domain 1: Physical health, Domain 2: Psychological, Domain 3: Social relations and Domain 4: Environment.

2. Well- Being Scale developed by Jagsharabu Singh and Asha Gupta. It consists of five sub-scales namely physical well-being, mental well-being, social well-being, emotional well-being and spiritual well-being. Each sub scale has ten items and there are 50 items in total. Scores on all the sub scales are added up to get the composite score as total wellbeing. Test- retest reliability of the scale was 0.98 and split half reliability was 0.96 .

\section{Procedure}

100 educated Muslim Housewives (Post Graduate) and 100 Muslim housewives having only primary education ( $0-8^{\text {th }}$ Class) of age range 23 to 45 , belonging to Sir Syed colony of Aligarh 


\section{Effect of Education on Quality of Life and Well Being}

district were taken for the study using snow ball sampling method. Questionnaires were filled by the investigators themselves by paying a visit at their residence. Subjects were informed about the purpose of collecting the data and consent was taken from them. They were assured that their confidentiality will be maintained.

\section{RESULTS}

Table 1: Shows significance of difference between educated and uneducated Muslim females on various dimensions of well being. Though overall well being of educated females were more than uneducated females but this difference was not significant at 0.05 level. Significant difference was found in 3 domains of well being : Mental well being, Social well being and Emotional well being. Educated females were more Social $(X=37.15)$ less Emotional $(X=34.15)$ and more mentally strong $(\mathrm{X}=41.65)$ as compared to uneducated females and this difference was significant at .05 level. Though differences in physical and spiritual dimensions were also found but this difference was not significant at .05 level.

Table 1 Showing Mean, SD And t Value Of Well Being And Its Dimensions

\begin{tabular}{|c|c|c|c|c|c|}
\hline Dimensions & $\mathbf{N}$ & MEAN & SD & $T$ & $\mathbf{P}$ \\
\hline $\begin{array}{l}\text { Educated } \\
\text { OWB } \\
\text { Uneducated }\end{array}$ & $\begin{array}{l}100 \\
100\end{array}$ & $\begin{array}{l}1.77 \\
1.75\end{array}$ & $\begin{array}{l}12.96 \\
15.13\end{array}$ & .85 & .39 \\
\hline $\begin{array}{l}\text { Educated } \\
\text { PHW } \\
\text { Uneducated }\end{array}$ & $\begin{array}{l}100 \\
100\end{array}$ & $\begin{array}{l}33.64 \\
33.42 \\
\end{array}$ & $\begin{array}{l}4.90 \\
5.41\end{array}$ & .301 & .764 \\
\hline $\begin{array}{l}\text { Educated } \\
\text { MWB } \\
\text { Uneducated }\end{array}$ & $\begin{array}{l}100 \\
100\end{array}$ & $\begin{array}{l}41.65 \\
40.24\end{array}$ & $\begin{array}{l}5.65 \\
5.36\end{array}$ & 1.8 & .051 \\
\hline $\begin{array}{l}\text { Educated } \\
\text { SOWB } \\
\text { Uneducated }\end{array}$ & $\begin{array}{l}100 \\
100\end{array}$ & $\begin{array}{l}37.15 \\
34.40\end{array}$ & $\begin{array}{l}3.75 \\
3.85\end{array}$ & 5.11 & .000 \\
\hline $\begin{array}{l}\text { Educated } \\
\text { EWB } \\
\text { Uneducated }\end{array}$ & $\begin{array}{l}100 \\
100\end{array}$ & $\begin{array}{l}34.15 \\
36.93\end{array}$ & $\begin{array}{l}6.55 \\
5.56\end{array}$ & 3.23 & .001 \\
\hline $\begin{array}{l}\text { Educated } \\
\text { SPWB } \\
\text { Uneducated }\end{array}$ & $\begin{array}{l}100 \\
100\end{array}$ & $\begin{array}{l}31.34 \\
30.66\end{array}$ & $\begin{array}{l}7.08 \\
7.81\end{array}$ & .64 & .521 \\
\hline
\end{tabular}

*PWB-Physical Well Being, MWB-Mental Well Being, SOWB-Social Well Being, EWBEmotional Well Being, SPWB-Spiritual Well Being. 


\section{Effect of Education on Quality of Life and Well Being}

Table 2: Shows significance of difference between educated and uneducated Muslim females on various dimensions of Quality of life. Overall QOL was better of educated females $(\mathrm{X}=2.38)$ as compared to uneducated females $(\mathrm{X}=2.24)$ and the difference was significant at .05 level. Significant difference was found on three dimensions of QOL: Physical Health, Psychological Health and Social Relation. Educated females were having better Physical Health $(\mathrm{X}=60.12)$ better Psychological Health $(X=64.71)$ and better Social relation $(X=65.78)$ as compared to uneducated females and this difference was significant at .05 level. There was no significant difference in Environmental relation.

Table 2 Showing: Showing Mean, SD And t Value Of Quality of Life Dimensions

\begin{tabular}{|c|c|c|c|c|c|}
\hline Dimensions & $\mathbf{N}$ & MEAN & SD & $T$ & $\mathbf{P}$ \\
\hline $\begin{array}{l}\text { Educated } \\
\text { QOL } \\
\text { Uneducated }\end{array}$ & $\begin{array}{l}100 \\
100\end{array}$ & $\begin{array}{l}2.38 \\
2.24\end{array}$ & $\begin{array}{l}18.25 \\
20.55\end{array}$ & 5.02 & .000 \\
\hline $\begin{array}{l}\text { Educated } \\
\text { PH } \\
\text { Uneducated }\end{array}$ & $\begin{array}{l}100 \\
100\end{array}$ & $\begin{array}{l}60.12 \\
57.54\end{array}$ & $\begin{array}{l}9.08 \\
9.14\end{array}$ & 2.00 & .04 \\
\hline $\begin{array}{l}\text { Educated } \\
\text { PS } \\
\text { Uneducated }\end{array}$ & $\begin{array}{l}100 \\
100\end{array}$ & $\begin{array}{r}64.71 \\
52.00\end{array}$ & $\begin{array}{l}64.8 \\
9.72\end{array}$ & 1.93 & .05 \\
\hline $\begin{array}{l}\text { Educated } \\
\text { SOR } \\
\text { Uneducated }\end{array}$ & $\begin{array}{l}100 \\
100\end{array}$ & $\begin{array}{r}65.78 \\
61.48\end{array}$ & $\begin{array}{r}10.40 \\
10.75\end{array}$ & 2.87 & .005 \\
\hline \begin{tabular}{l}
\multicolumn{1}{c}{ Educated } \\
EVR \\
Uneducated
\end{tabular} & $\begin{array}{l}100 \\
100\end{array}$ & $\begin{array}{r}53.94 \\
53.93\end{array}$ & $\begin{array}{r}7.47 \\
7.75\end{array}$ & .009 & .993 \\
\hline
\end{tabular}

*QOL- Overall Quality Of Life, PH-Physical Health, PS- Psychological Health, SOR-Social Relationship, EVR- Environmental Relationship.

\section{DISCUSSION}

The study was conducted to see Quality of Life and Well-Being of educated and uneducated females. Education was found to have positive effect on Quality of life and well-being. First objective of our study was to assess and compare QOL of educated and non educated Muslim females. Our study indicated that there was significant difference in three domains of Quality of life (Physical Health, Psychological Health and Social Relationship) in both the groups.

(c) The International Journal of Indian Psychology, ISSN 2348-5396 (e)| ISSN: 2349-3429 (p) | 123 


\section{Effect of Education on Quality of Life and Well Being}

Educated females were having better physical health, psychological health and social relationship as compared to uneducated females. Whereas there was no significant difference found in the fourth domain i.e. environmental relation.

Education is a basic determinant of QOL of individuals. People with limited skills and competencies are excluded from good jobs and have fewer prospects for economic prosperity. According to research, early schools leaves face a higher risk of social exclusion and poverty and are also less likely to participate in the civic life and political affairs of the society. This is also because education enhances people's understanding of the world they live in, and hence the perception of their ability to influence it (Europe 2020 target). Probably these are the factors why education affects QOL.

Evidence of higher education affecting quality of life is well documented in the education literature. Oreopoulos and Salvanes (2011) in a comprehensive review of the non pecuniary benefits of education concluded that education is one of the most important predictors of one's health status, Employability and probability of being married, all are well known predictors of QOL. (Oswald 1997, Layard 2005, Layaed et al. 2013).

Many scholars have found a positive and statistically significant association between education and self rated life satisfaction across different international data sets and time periods (eg ; Blanchflower and Oswald 2004, Easterlin 2001, Ferrer-i-Carbonell 2005, Graham and Pettinato 2002)

Yet there have also been other studies that have documented either a negaitive or a statistically insignificant effect of education on the way people report their QOL; (eg, Melin et.al 2003, Flouri 2004, Powdthavee 2008, Shields et al. 2009)

Other objective of this study was to assess and compare well being of educated and uneducated Muslim females. Our study indicated that educated females scored higher ob social, mental and emotional well-being and the difference found between both the groups was significant. Whereas no significant difference was found on the remaining dimensions i.e. Spiritual and Physical well being. A wide variety of studies have investigated the relationship between education and wellbeing.

Some studies identify a positive relationship between education and well-being, while others find that middle level education is related to the highest level of well-being (Dalan et.al 2008). Various studies have shown positive effects on individual well-being and health outcome (Feinstein 2002; Feinstein et al 2003; Subates and Feinstein 2004; Hammond \& Feinstein 2006, Feinstein et al 2008).Poor health and low level of formal education have been found to reduce psychological well-beings (Thoits, 1983). 


\section{Effect of Education on Quality of Life and Well Being}

Another general finding is that the relationship between early formal education and perceived wellbeing is negative for some groups. For example, Alwin (1987) found that, after due allowance had been made for differences in income levels, people with more education were less satisfied with their global life situation. Several theories provide explanations for this finding (Rosenberg 1981; Gooderham 1987). In the social psychological perspective, reference group theory is perhaps the most dominant approach. This theory can be viewed as arguing that negative correlations between education, life satisfaction and perceived wellbeing arise because the relatively better educated groups tend to have higher aspirations, expectations and demands and, as a result, employ other reference standards in assessing their subjective life situation.

Individual perception of QOL may affect subjective well being indicating positive and negative evaluation of life. Thus SWB can be considered as a frame for any appraisals that people make about their lives (Dinener, Lucas 2006). Education influences people's perception of their QOL. It promotes social, cultural and political participation as an end in itself and as a means for improving the welfare of people. The influence of educational experiences on preferences, expectations, feelings and emotional states is integrated as a multiple force which contributes not only towards the shaping of personality characteristics but also to social psychological traits such as self esteem and perceived personal well-being.

Education improves well-being because it increases access to non alienated paid work and economic resources that increase the sense of control over life, as well as access to stable social relationships, especially marriage, that increases social support (Ross CE, Van Willigen M,1997)

\section{LIMITATIONS}

While interpreting the findings of our study it is important to acknowledge some of its limitation. Though a number of variables were kept constant like both the groups were matched in: Gender (Female), Age (23-40), Residential area (Sir Syed Nagar), Family Type (Nuclear) and Socio Economic status (Lower Middle according to Kuppuswamy's Socio-Economic Status Scale). Whereas various other confounding variables were not kept constant like: No. off offspring, Husbands education, Physical illness among family members, recent traumatic event etc. these variables can have positive or adverse effect on QOL and well-being of females. Hence in future studies all the factors should be kept constant in order to know exact effect of education on QOL and well-being.

\section{CONCLUSION}

The realization of the importance of education has been increased with changing time. Due to education the marriage prospects has been increased. Men now prefer marrying educated and employed girls rather than taking dowry. Moreover, the job opportunities of girls lead to economic independence. Education and employment are no more confined to men. With the changing time educational level of Muslim women is going up. There is a change in the attitude 


\section{Effect of Education on Quality of Life and Well Being}

of males towards liberalization in education of women. Moreover, education enabled the respondents to supervise and assist in their children's studies at home. A better educated wife has better status in the family.

There is an old proverb that says :- " If you educate a man, you educate an individual, but if you educate a woman, you educate a family" I would like to take it one step further and say that in today's economy, if you educate a woman, you strengthen a family and a nation, and that ultimately benefits everyone.

\section{Acknowledgments}

The author appreciates all those who participated in the study and helped to facilitate the research process.

\section{Conflict of Interests}

The author declared no conflict of interests.

\section{REFERENCES}

Alwin, D. F. 1987. Distributive Justice and Satisfaction with Material Well-being. American Sociological Review 52: 83--95.

Blanchflower, D., \& Oswald, A.J. (2004). Well-being over time in Britain and the USA. Journal of Public Economics, 88(7), 1359-1386

Cummins, R. (2000). Objective and Subjective Quality of Life: an interactive model.,Social Indicators Research, 55-72.

Diener, E., Lucas, R.E. and Scollon, C. (2006). Beyond the hedonic treadmill: revising the adaptation theory of well-being, Psychological Science, 61, 305-314

Dolan et al, 2008a Sebates R and Hammond C (2008): The impact of lifelong learning on happiness and well being.

Easterlin, R. A. (2007). The Escalation of Material Goals: Fingering the Wrong Culprit, Psychological Inquiry, 18(1), 31-33.

Easterlin, R.A. (2001). Income and happiness: towards a unified theory. Economic Journal, 111(473), 465-484.

Europe 2020 Target: Early leavers from education and training, European Commission.

Feinstein, L. (2002). Quantitative Estimates of the Social Benefits of Learning, 2: Health (Depression and Obesity). Report No.6, Centre for Research on the Wider Benefits of Learning, Institute of Education.

Feinstein, L. F., Galindo-Rueda, F. and Vignoles, A. (2004). The Labour Market Impact of Adult Education and Training: a Cohort Analysis. Scottish Journal of Political Economy, pp. 266-280. 


\section{Effect of Education on Quality of Life and Well Being}

Feinstein, L., Hammond, C., Woods, L., Preston, J. and Bynner, J. (2003). The Contribution of Adult Learning to Health and Social Capital. Report No.8. Centre for Research on the Wider Benefits of Learning, Institute of Education

Feinstein, L.F. and Vignoles, A. (2008). Individual differences in the pathways into and beyond Higher Education in the UK: A lifecourse approach. Journal of Social Issues, 64(1), 115-133.

Ferrer-i-Carbonell, A. (2005). Income and well-being: an empirical analysis of the comparison income effect. Journal of Public Economics, 89(5-6), 997-1019.

Flouri, E. (2004). Subjective well-being in midlife: the role of involvement of and closeness to parents in childhood. Journal of Happiness Studies, 5(4), 335-358.

Gasper, D. (2010).Understanding the diversity of conceptions of well-being and quality-oflife.Journal of Socio-Economics, 39, 351-360.

Gooderham, P. N. 1987. Reference Group Theory and Adult Education. Adult Education Quarterly 37:140-151.

Graham, C., \& Pettinato, S. (2002). Happiness and Hardship: Opportunity and Insecurity in New Market Economies. Washington DC: Brookings Institution Press

Gururaj, Maheshwaran (2014). Kuppuswamy’s Socio-Economic Status Scale - A Revision of Income Parameter For 2014. International Journal of Recent Trends in Science And Technology, ISSN 2277-2812 E-ISSN 2249-8109, Volume 11, Issue 1, 2014 pp 01-02.

Layard, R. (2005). Happiness: Lessons from a New Science. London and New York: Penguin Press.

Layard, R., Clark, A.E., Cornaglia, F., Powdthavee, N., \& Vernoit, J. (2013). What predicts a successful life? IZA Discussion Paper No. 7682, University of Bonn.

Melin, R., Fugl-Meyer, K.S., \& Fugl-Meyer, A.R. (2003). Life satisfaction in 18- to 64-yearold Swedes: in relation to education, employment situation, health and physical activity. Journal of Rehabilitation Medicine, 35(2), 84-90

Michalos, AC 2007, Education, happiness and wellbeing, paper written for the International Conference on 'Is happiness measurable and what do those measures mean for public policy?', University of Rome, April.

Oreopoulos, Philip, and Kjell G. Salvanes. 2011. "Priceless: The Non pecuniary Benefits of Schooling." Journal of Economic Perspectives, 25(1): 159-84.

Oswald, A. J. and Powdthavee, N. (2007). Death, Happiness, and the Calculation of Compensatory Damages, IZA Discussion Papers3159, Institute for the Study of Labor (IZA).

Oswald, A.J. (1997). Happiness and economic performance. Economic Journal, 107(445), 18151831

Powdthavee, N. (2008). Putting a price tag on friends, relatives, and neighbors: using surveys of life-satisfaction to value social relationships. Journal of Socio-Economics, 37(4), 14591480.

Rosenberg, M. 1981. The Self-concept: Social Product and Social Force. In: M. Rosenberg et al., eds., Social Psychology, (593--624). New York: Basic Books. 


\section{Effect of Education on Quality of Life and Well Being}

Ross CE, Van Wiligen M. J Health Soc.Behav.1997 Sep; 38 (3): 275-97.

Shields, M.A., Wheatley-Price, S., \& Wooden, M. (2009). Life satisfaction and the economic and social characteristics of neighborhoods. Journal of Population Economics, 22(2), 421- 443

Shin., D. and Johnson, D. (1978).Avowed happiness as an overall assessment of the quality of life. Social Indicators Research, 5, 475-492.

Singh, J. and Gupta, A. (2001). Well Being Scale, Department of Education, Chandigarh : Panjab University.

Smith, D. (1973) The Geography of Social Well-Being in the United States, Mcgraw-Hill, New York.

The WHOQOL Group. (1994a). Development of the WHOQOL: Rationale and current status. International Journal of Mental Health, 23 (3), 24-56.

Thoits, Peggy A. Multiple Identities and Psychological Well-Being: A Reformulation and Test of the Social Isolation Hypothesis. American Sociological Review 48, 2: 174-187.

Veenhoven, R. (1999). Quality-of-Life in Individualistic Society. Social Indicators Research, 48, 157-186.

How to cite this article: S Javed, S Javed, A Khan (2016), Effect of Education on Quality of Life and Well Being, International Journal of Indian Psychology, Volume 3, Issue 4, No. 58, ISSN 2348-5396 (e), ISSN: 2349-3429 (p), DIP: 18.01.053/20160304, ISBN: 978-1-365-24976-

1

(c) The International Journal of Indian Psychology, ISSN 2348-5396 (e)| ISSN: 2349-3429 (p) | 128 